Situs Jurnal : $\underline{\text { http://ejournal.stiepancasetia.ac.id/index.php/jieb }}$

Jilid 5 Nomor 3 November 2019

Hal 362 - 370

\title{
ANALISIS PENERAPAN PENGENDALIAN INTERN PIUTANG PADA CV BERKAT KARYA DIESEL BANJARMASIN
}

\section{Imawati Yousida*}

Abstract: The purpose of this study was to determine the application of accounts receivable internal control on the CV Berkat Karya Diesel Banjarmasin that runs so far and should be done. The method used is descriptive qualitative research conducted by observing a particular object. The results showed that the internal control system of accounts receivable at CV Berkat Karya Diesel Banjarmasin is still not appropriate, because there is still a dual function of the sales department that doubles as part of sales as well as invoicing, where invoicing should be done by the accounting department. CV Berkart Karya Diesel Banjarmasin must have management to determine the authority and responsibility, organize and develop the people who work at this company

\section{Keywords: Internal Control, Receivables}

Abstrak: Tujuan dari penelitian ini untuk mengetahui penerapan pengendalian intern piutang pada CV Berkat Karya Diesel Banjarmasin yang berjalan selama ini dan yang seharusnya dilakukan. Metode yang digunakan adalah secara deskriptif kualitatif yaitu penelitian yang dilakukan dengan cara mengamati objek tertentu. Hasil penelitian menunjukkan bahwa sistem pengendalian intern piutang pada CV Berkat Karya Diesel Banjarmasin masih belum tepat, karena masih adanya perangkapan fungsi bagian penjualan yang merangkap sebagai bagian penjualan sekaligus sebagai pembuat faktur, dimana pembuat faktur seharusnya dilakukan oleh bagian akuntansi. CV Berkart Karya Diesel Banjarmasin harus memiliki manajemen untuk menentukan wewenang dan tanggung jawab, mengorganisasikan dan mengembangkan orangorang yang bekerja pada perusahaan ini.

\section{Kata kunci: Pengendalian Intern, Piutang}

\section{Latar Belakang}

Di dalam dunia usaha, terdapat beberapa strategi yang digunakan oleh penjual untuk meningkatkan volume penjualan maupun kesetiaan pelanggan. Diantara sekian banyak strategi, pemberian piutang dagang (penjualan secara kredit) merupakan salah satu strategi penjualan yang banyak dilakukan oleh para pengusaha. Selain karena cukup praktis, tingkat sistem penjualan kredit cepat berkembang dan mendapatkan respon yang baik dari kalangan masyarakat. Penjualan dari suatu produk yang dihasilkan oleh suatu perusahaan merupakan salah satu faktor penentu dalam kegiatan perusahaan. Kondisi ini memotivasi perusahaan dalam pelaksanaan sistem penjualan kredit yang baik dalam usaha meningkatkan pendapatan. Penjualan kredit merupakan salah satu sumber penerimaan kas bagi perusahaan, khususnya pelunasan piutang. Sebagai salah satu sumber pendapatan, penjualan kredit menempati posisi yang lebih besar dibandingkan penjualan tunai. Hal seperti ini disebabkan karena pelanggan lebih suka untuk melakukan transaksi secara kredit. Praktiknya penjualan kredit tidak seperti penjualan tunai. Keterlambatan pembayaran dan kemungkinan sulitnya penagihan pada 
pelanggan yang menunggak hingga tidak tertagihnya piutang masih terjadi. Pengendalian intern sangatlah dibutuhkan dalam sistem pengendalian intern piutang untuk mengurangi tingkat resiko kerugian yang akan dialami perusahaan.

Sistem pengendalian intern yang memadai seperti struktur organisasi yang memisahkan fungsional secara jelas, sistem prosedur danpendelegasian wewenang untuk setiap bagian, praktek yang sehat dan pegawai yang cakap seluruhnya dapat terwujud apabila sistem pengendalian intern dapat dijalankan dengan baik sehingga dapat memperkecil resiko kerugian perusahaan. Prinsipnya pengendalian intern sangat dipercaya dapat melaksanakan kegiatan yang bertujuan untuk mendapatkan sasaran dalam menjalankan sistem akuntansi pada piutang. Menurut Mulyadi (2016:163) pengendalian intern adalah: "Suatu cara untuk mengarahkan, mengawasi, dan mengukur sumber daya suatu organisasi. Ia berperan penting untuk mencegah dan mendeteksi penggelapan (fraud) dan melindungi sumber daya organisasi baik yang berwujud (seperti mesin dan lahan) maupun tidak berwujud (seperti reputasi atau hak kekayaan intelektual seperti merek dagang)."

CV Berkat Karya Diesel Banjarmasin merupakan perusahaan penjualan sparepart alat berat yang beralamat di jalan Ahmad Yani Km.12, Banjarmasin. Perusahaan ini lebih banyak melakukan penjualan secara kredit daripada secara tunai. Karena hanya mengandalkan penjualan secara kredit mengakibatkan perputaran kas pada perusahaan lambat karena penagihan piutang baru bisa dilakukan dua minggu atau satu bulan setelah invoice dibuat. Selain hal tersebut pada CV Berkat Karya Diesel Banjarmasin dalam pelaksanaan prosedur penjualan kredit selama ini adanya Perangkapan bagian penjualan (sales) merangkap sebagai pembuat faktur. Otorisasi penjualan untuk persetujuan memberikan kredit atas penjualan selama ini tidak dilakukan oleh bagian penjualan saja, karena customer selalu mengganggap owner adalah teman. Dalam pemberian piutang selama ini kepada customer berdasarkan unsur kepercayaan saja. Berdasarkan uraian diatas dapat dilakukan penelitian dengan judul "Analisis Penerapan Pengendalian Intern Piutang pada CV Berkat Karya Diesel Banjarmasin”.

\section{Kajian Literatur}

Menurut Mulyadi (2016:129) pengendalian intern adalah Sistem pengendalian intern meliputi struktur organisasi, metode dan ukuran-ukuran yang dikoordinasikan untuk menjaga aset organisasi, mengecek ketelitian dan 7 keandalan data akuntansi, mendorong efisiensi dan mendorong dipatuhinya kebijakan manajemen. Unsur pokok pengendalian intern adalah:

1. Struktur organisasi yang memisahkan tanggungjawab fungsional secara tegas.

2. Sistem wewenang dan prosedur pencatatan yang memberikan perlindungan yang cukup terhadap kekayaan, utang, pendapatan dan biaya.

3. Praktik yang sehat dalam melaksanakan tugas dan fungsi setiap unit organisasi

4. Karyawan yang mutunya sesuai dengan tanggungjawabnya.

Pengendalian intern terdiri dari 5 komponen yang saling berhubungan. Komponen ini didapat dari cara manajemen menjalankan bisnisnya dan terintegrasi dengan proses manajemen. Walaupun komponen-komponen tersebut dapat diterapkan kepada semua entitas, perusahaan yang kecil dan menengah dapat menerapkannya berbeda dengan perusahaan besar. Dalam hal ini pengendalian dapat tidak terlalu formal dan tidak terlalu terstruktur, namun pengendalian intern tetap dapat berjalan dengan efektif. Adapun 5 komponen pengendalian intern tersebut adalah:

1. Control Environment (Lingkungan Pengendalian) pengendalian memberikan nada pada suatu organisassi, mempengaruhi kesadaran pengendalian dari para anggotanya.

2. Risk Assesment (Penilaian Risiko) Seluruh entitas menghadapi berbagai macam resiko dari luar dan dalam yang harus ditaksir. 
3. Control Activities (Aktivitas Pengendalian) Control activities adalah kebijakan dan prosedur membantu meyakinkan manajemen bahwa arahannya telah dijalankan

4. Information and Communication (informasi dan komunikasi) Informasi yang bersangkutan harus diidentifikasi, tergambar dan terkomunikasi dalam sebuah form dan timeframe yang memungkinkan orang-orang menjalankan tanggung jawabnya.

5. Monitoring (Pemantauan) Sistem pengendalian internal perlu diawasi, sebuah proses untuk menentukan kualitas performa sistem dari waktu ke waktu.

Penjualan kredit adalah kegiatan penjualan yang terdiri dari transaksi penjualan barang atau jasa, baik secara kredit maupun tunai. Dalam transaksi penjualan kredit, jika order dari pelanggan telah dipenuhi dengan pengiriman barang atau penyerahan jasa, untuk jangka waktu tertentu perusahaan memiliki piutang kepada pelanggannya. Kegiatan penjualan secara kredit ini ditangani oleh perusahaan melalui sistem penjualan kredit

Jika kebijakan penjualan kredit terlalu ketat akan memperkecil resiko tidak tertagihnya piutang, tetapi kebijakan penjualan kredit yang terlalu longgar akan memperbesar resiko tidak tertagihnya piutang. Menerapkan sistem penjualan kredit yang sistematis dan sesuai dengan kondisi perusahaan agar kelancaran aktivitas penjualan kredit dan penyampaian hasil informasi dapat terjamin. dari:

Unsur-unsur pokok pengendalian internal penjualan kredit (Mulyadi, 2016:226) terdiri

1. Organisasi

Fungsi Penjualan harus terpisah dari fungsi kredit Pemisahan kedua fungsi ini dimaksud untuk menciptakan pengecekan terhadap penjualan kredit. Fungsi akuntansi harus terpisah dari fungsi penjualan dan fungsi kredit Fungsi akuntansi harus terpisah dari fungsi kas Pemisahan

2. Sistem Otorisasi dan Prosedur Pencatatan

Otorisasi terjadinya transaksi dilakukan dengan membubuhkan tandatangan oleh yang memiliki wewenag untuk itu pada dokumen sumber atau dokumen pendukung. Dengan demikian karena setiap transaksi terjadi dengan otorisasi dari yang berwenang dan dicatat melalui prosedur pencatatan tertentu, maka kekayaan perusahaan akan terjamin keamanannya dan data akuntansi yang dicatat terjamin ketelitian dan keandalannya.

3. Praktik yang sehat

a. Penggunaan formulir yang bernomor urut tercetak.

b. Secara periodik fungsi akuntansi mengirimkan pernyataan piutang kepada setiap debitur untuk menguji ketelitian catatan piutang yang diselenggarakan oleh fungsi tersebut.

c. Secara periodik diadakan rekonsiliasi kartu piutang dengan rekening control piutang dalam buku besar.

\section{Kecakapan atas karyawan}

Piutang adalah mengacu pada sejumlah tagihan yang akan diterima oleh perusahaan (umumnya dalam bentuk kas) dari pihak lain, baik sebagai akibat penyerahan barang dan jasa secara kredit. Dwi Martani, (2014:193), Pengertian piutang dijabarkan oleh beberapa pakar akuntansi, yang "mendefinisikan piutang merupakan klaim suatu perusahaan pada pihak lain". Menurut Zaki (2014:16) piutang usaha merupakan piutang usaha yang timbul dari penjualan barang-barang atau jasa-jasa yang dihasikan perusahaan yang akan dilunasi dalam jangka waktu kurang dari satu tahun. 
Unsur pengendalian dalam penagihan piutang sebagai berikut:

1. Organisasi

Fungsi akuntansi harus terpisah dari fungsi penagihan dan fungsi penerimaan kas. Fungsi penerimaan kas harus terpisah dari fungsi akuntansi

2. Sistem otorisasi dan prosedur pencatatan

Debitur diminta untuk melakukan pembayaran dalam bentuk cek atas nama atau dengan cara pemindah bukuan (giro billyet). Fungsi penagihan melakukan penagihan hanya atas dasar daftar piutang yang harus ditagih di buat oleh fungsi akuntansi. Pengkreditan rekening pembantu piutang oleh fungsi akuntansi (bagian piutang) harus didasarkan atas surat pemberitahuan yang berasal dari debitur.

3. Praktek yang sehat

Hasil perhitungan kas harus direkam dalam berita acara perhitungan kas dan disetor penuh ke bank dengan segera. Para penagih dan kasir harus diasuransikan (fidelity bond insurance).Kas dalam perjalanan (baik yang ada ditangan bagian kasir maupun di tangan penagih perusahaan), harus diasuransikan (cash in safe dan crash in transit insurance)."

Dokumen Yang Terkait, sesuai dengan yang telah dikemukankan oleh Mulyadi (2016 :41) yaitu:

1. Surat Order Pengiriman

2. Tebusan Kredit

3. Surat Pengakuan

4. Bukti Memorial

Fungsi Yang Terkait Dalam Penagihan Piutang dalam sistem penerimaan kas dari penagihan piutang adalah sebagai berikut:

1. Fungsi Surat Masuk

2. Fungsi Penagihan

3. Fungsi Kasir

4. Fungsi Akuntansi

5. Fungsi pemeriksaan intern

Melihat komponen dan unsur unsur pengendalian intern pada penjualan kredit dan piutang dari fenomena yang selama ini terjadi maka dapat dijelaskan pada gambar kerangka berpikir sebagai ditunjukkan pada Gambar 1.

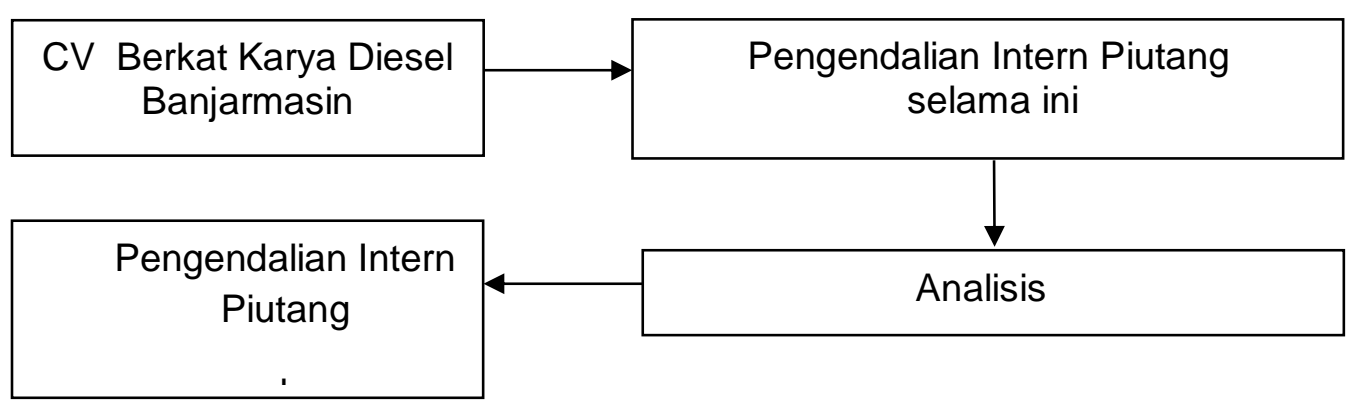

\section{Gambar 1 : Kerangka Berfikir Penelitian}




\section{Metode Penelitian}

Jenis penelitian yang digunakan dalam penelitian ini adalah penelitian kualitatif dengan desain penelitian deskriptif. Metode kualitatif digunakan untuk mendapatkan data yang mendalam, suatu data yang mengandung makna atau data yang sebenarnya. Dengan metode analisis yang digunakan untuk memperoleh gambaran. seperti kegiatan operasional perusahaan, struktur organisasi dan visi-misi perusahaan. Data kuantitatif yaitu data yang dinyatakan dalam bentuk angka. Berupa data yang berasal dari CV. Berkat karya Diesel di Banjarmasin mengenai pengendalian intern atas piutang Data kualitatif yaitu data yang dinyatakan dalam bentuk kata, kalimat, dan gambar. Berupa hasil wawanca dan observasi yang ada di CV. Berkat karya Diesel di Banjarmasin Pengumpulan data yang dilakukan oleh penulis untuk mendukung penelitian ini membutuhkan data yang relevan sebagai berikut dengan cara Wawancara yaitu tanya jawab yang dilakukan baik secara langsung berhadapan dengan yang diwawancarai maupun secara tidak langsung. Penelitian keperpustakaan mempelajari buku literatur, jurnal penelitian, penelitian terdahulu, Observasi dengan turun kelapangan untuk mengamati perilaku dan aktivitas terkait dengan penjualan kredit dan piutang yang terjadi pada CV. Berkat karya Diesel. Berdasarkan permasalahan yang ada terkait dengan piutang dagang maka teknik analisis penelitian ini adalah dalam penelitian ini dianalisa secara deskriptif yaitu alat analisis yang membandingkan antara pengendalian intern secara teori dengan pengedalian intern piutang yang selama ini pada perusahaan kemudian menarik kesimpulan dengan memberikan masukan dan saran atas unsur unsur pengendalian yang sesuai dengan teori.

\section{Hasil Penelitian}

CV.Berkat Karya Diesel adalah perusahaan yang bergerak dibidang suplier perdagangan umum. Sebagian besar usaha yang dijalankan berupa penjualan barang suku cadang (sparepart) alat berat.

Berdasarkan hasil penelitian terkait dengan data dan komponen pengendalian intern piutang pada CV Berkat Karya Diesel Banjarmasin adalah :

1. Data Penjualan dan Piutang Periode 2016 s.d 2017

Tabel 1 Data Penjualan Kredit dan Piutang

\begin{tabular}{rrlr}
\hline Tahun & Penjualan Kredit & \multicolumn{2}{c}{ Piutang } \\
\cline { 3 - 4 } & & Terbayar & \multicolumn{1}{c}{ Tidak Terbayar } \\
\hline 2016 & 1.569 .356 .200 & 1.234 .688 .300 & 334.667 .900 \\
\hline 2017 & 1.747 .246 .400 & 1.336 .456 .100 & 410.790 .300 \\
\hline 2018 & 1.459 .357 .100 & 1.048 .347 .800 & 411.009 .300 \\
\hline
\end{tabular}

2. Komponen pengendalian intern piutang

Komponen pengendalian intern selama ini CV Berkat Karya Diesel Banjarmasin adalah:

a. Lingkungan Pengendalian

Lingkungan pada CV. Berkat Karya Diesel Banjarmasin Pengendalian intern meliputi struktur organisasi yang digunakan untuk memisahkan tanggung jawab dan wewenang secara tegas masing-masing bagian agar tidak terjadi kecurangan dalam penyelenggaraan transaksi. Dengan pemisahan tugas kemungkinan terjadinya tindak kecurangan dapat diperkecil selain itu juga dapat mencerminkan transaksi yang sesungguhnya. Penetapan wewenang dan tanggung jawab merupakan pengembangan dari struktur organisasi, yang 
secara garis besar di wujudkan dalam bentuk pemisahan fungsi-fungsi. Pemisahan fungsi pada CV. Berkat Karya Diesel Banjarmasin belum baik, dikarenakan masih adanya rangkap tugas dan wewenang dalam perusahaan yaitu bagian penjualan yang juga merangkap sebagai bagian pembuat faktur yang seharusnya dilakukan oleh bagian akuntansi. Dengan tidak cukup jelasnya pemisahan fungsi tersebut, maka manajemen perusahaan belum mampu dalam menilai bagian-bagian yang dipimpinnya, apakah setiap fungsi telah melaksanakan tugasnya dengan baik. Mengingat CV. Berkat Karya Diesel ini semakin berkembang sebaiknya diadakan penetapan tanggung jawab fungsi yang jelas. Selain pemisahan fungsi, perusahaan ini juga tidak menerapkan pendelegasian wewenang sesuai dengan struktur organisasi perusahaan.

b. Penilaian Resiko

Pengendalian ditentukan berdasarkan resiko yang dikelola untuk menghindari kesalahan dan kecurangan yang berakibat misstatement terhadap laporan keuangan. Namun hal ini tidak terbatas pada resiko laporan keuangan saja, pengendalian juga diterapkan untuk resiko lain, termasuk resiko bisnis dan operasi. Penaksiran resiko yang dilakukan oleh manajemen agar penyajian informasi piutang yang wajar. Selain itu perusahaan belum mengenali dan mempelajari resiko resiko yang ada, serta membentuk aktivitas-aktivitas pengendalian yang diperlukan untuk menghadapi hal tersebut. Kegiatan pencatatan dan penagihan piutang pada CV. Berkat Karya Diesel tidak menetapkan resiko yang mungkin timbul dari kegagalan penagihan piutang maka sangat lah penting untuk melakukan kajiankajian untuk menentukan tingkat resiko yang mungkin terjadi dari perubahan keadaan sebagai berikut:

1) Pola bisnis atau transaksi yang memerlukan prosedur prosedur yang baru

2) Adanya perubahan standar kualitas

3) Perubahan yang berkaitan dengan revisi sistem dan teknologi baru yang digunakan untuk pengelolaan informasi

3. Aktivitas pengendalian

Aktivitas Pengendalian merupakan kebijakan yang membantu dan memastikan arahan dari manajemen dilaksanakan. Aktivitas pengendalian mempunyai tujuan dan diterapkannya diberbagai tingkat organisasi dan fungsi. Aktivitas pengendalian meliputi penerapan berbagai prosuder untuk dijamin dipatuhi kebijakan manajemen. Umumnya aktivitas pengendalian dapat digolongkan sebagai kebijakan dan prosuder berkaitan dengan review terhadap kinerja, penggolongan informasi, pengendalian fisik dan pemisahan tugas. Dalam penelitian ini CV. Berkat Karya Diesel Banjarmasin belum melaksanakan aktivitas pengendalian intern piutang yang baik. Dapat dilihat dari masih terdapatnya penggabungan tugas dan wewenang di perusahaan.

\section{Informasi dan Komunikasi}

Informasi dan komunikasi adalah bagaimana mengidentifikasi, memahami, dan melakukan pertukaran informasi dalam suatu bentuk dan waktu yang menungkinkan setiap personil dalam perusahaan melaksanakan tanggung jawab mereka. Informasi yang disampaikan dari setiap bagian diproses dengan cepat dan akurat. Informasi dimulai dari laporan debitur yang ingin memberi barang secara kredit. Sistem informasi yang relevan dengan tujuan pengendalian intern menyangkut sistem akuntansi yang terdiri dari metode dan pencatatan yang telah diterapkan oleh perusahaan untuk mengidentifikasi, menyusun, menganalisa, mengolongkan ,mencatat, dan melaporkan transaksi tersebut serta bagaimana mengkomunikasikan dan memelihara pertanggung jawaban atas aset dan kewajiban yang 
terkait. Dalam penggunaan informasi dan komunikasi CV. Berkat Karya Diesel Banjarmasin dalam piutang cukup memadai dimana laporan-laporan mengenai piutang di input melalui komputerisasi dan dilaporkan untuk memberikan informasi pada laporan keuangan di bagian keuangan. Komunikasi yang berupa tindakan maupun lisan terutama yang berhubungan dengan proses penghimpunan belum berjalan cukup baik sehingga belum cukup mempermudah pengendalian intern perusahaan.

\section{Pengawasan}

Setiap karyawan harus diberikan tugas dan tanggung jawab yang sesuai berdasarkan dengan kemampuan, pengalaman dan kejujuran. Karena semua itu akan memberikan langkah yang baik bagi perusahaan dalam pencapaian tujuan perusahaan. Dari hasil penelitian yang dilakukan karyawan yang bekerja pada CV. Berkat Karya Diesel Banjarmasin terdiri dari beberapa pegawai bekerja yang tidak sesuai dengan latar pendidikannya, hal ini juga berdampak dengan kinerja perusahaan yang kurang efektif dikarenakan perusahaan memperlukan waktu lebih lama untuk membimbing dan mengarahkan pegawai yang sesuai dengan fungsi dan tanggung jawabnya.

Dokumen-dokumen yang terkait dengan Piutang

1. Surat Pesanan

2. Faktur Pejualan

3. Daftar tagihan

4. Laporan piutang harian pelanggan

5. Prosedur Piutang

Unsur-unsur Pengendalian Intern Piutang CV. Berkat Karya Diesel Banjarmasin yang berjalan selama ini

1. terdaparStruktur organisasi yang memisahkan tanggungjawab fungsional

Dalam hal ini CV. Berkat Karya Diesel Banjarmasin belum memisahkan tanggungjawab fungsional secara tegas. Karena masih adanya perangkapan fungsi, dimana bagian penjualan merangkap sebagai pembuat faktur.

2. Sistem wewenang dan prosedur pencatatan

Dalam hal ini sistem wewenang dan prosedur pencatatan pada CV Berkat Karya Diesel Banjarmasin dalam hal pemberian piutang tidak berjalan dengan baik karena hanya dijalankan berdasarkan unsur kepercayaan. unsur pengendalian piutang, otorisasi dan pencatatan, penjualan kredit (banyak penjualan kredit yang transaksinya dijamin oleh pemiliknya (karena customer merasa keluarga dari pemilik sehingga tidak sesuai SOP), dan database customernya tidak dibuat berdasarkan SOP), sehingga piutang selama ini kebijakannya salah, karena customer merasa yang punya perusahaan adalah keluarga sendiri prosedur penagihan piutang sulit, dan hal tersebut menjadikan piutang tidak tertagih bertambah.

3. Praktik yang sehat

Tidak diselenggarakannya pemeriksaan khusus oleh pimpinan perusahaan terhadap pencatatan pengajuan dan penerimaan piutang selama ini. Pemberian kredit selama ini hanya diputuskan oleh karyawan tanpa mengkonfirmasi kepada owner dan hanya sebatas direktur saja. Dalam hal ini tidak berjalan dengan baik karena karyawan yang ada melakukan perangkapan fungsi yang dapat mengakibatkan terjadinya kecurangan. 
4. Karyawan yang mutunya sesuai dengan tanggungjawabnya.

Dalam hal ini karyawan yang bekerja ada perusahaan masih terdiri dari beberapa karyawan bekerja yang belum sesuai dengan latar pendidikannya.

Unsur-Unsur Pengendalian Intern Piutang yang seharusnya. Unsur pengendalian dalam penagihan piutang sebagai berikut:

1. Organisasi

a. Fungsi akuntansi harus terpisah dari fungsi penagihan dan fungsi penerimaan kas

b. Fungsi penerimaan kas harus terpisah dari fungsi akuntansi

2. Sistem otorisasi dan prosedur pencatatan

a. Debitur diminta untuk melakukan pembayaran dalam bentu cek atas nama atau dengan cara pemindah bukuan (giro billyet)

b. Fungsi penagihan melakukan penagihan hanya atas dasa daftar piutang yang harus ditagih di buat oleh fungsi akuntansi.

c. Pengkreditan rekening pembantu piutang oleh fungsi akuntansi (bagian piutang) harus didasarkan atas surat pemberitahuan yang berasal dari debitur.

3. Praktek yang sehat

a. Hasil perhitungan kas harus direkam dalam berita acara perhitungan kas dan disetor penuh ke bank dengan segera.

b. Para penagih dan kasir harus diasuransikan (fidelity bond insurance).

c. Kas dalam perjalanan (baik yang ada ditangan bagian kasa maupun di tangan penagih perusahaan), harus diasuransikan (cash in safe dan crash in transit insurance).

4. Karyawan yang mutunya sesuai dengan tanggungjawabnya.

Untuk karyawan yang bekerja ada perusahaan ini agar sesuai dengan latar pendidikannya apalagi dibagian keuangan perusahaan dan dapat menjalan SOP yang dibuat oleh perusahaan.

Dokumen Yang disarankan

1. Surat Order Pengiriman

2. Tebusan Kredit

3. Surat Pengakuan

4. Bukti Memorial

\section{Kesimpulan dan Keterbatasan Penelitian}

Berdasarkan hasil penelitian dapat pada CV. Berkat Karya Diesel Banjarmasin adalah sebagai berikut:

1. Penerapan pengendalian intern piutang pada CV Berkat Karya Diesel Banjarmasin yang berjalan selama ini masih belum cukup baik, dimana belum ada pemisahan fungsi pada CV. Berkat Karya Diesel Banjarmasin dengan tegas, sehingga masih adanya rangkap tugas dan wewenang dalam perusahaan yaitu bagian penjualan yang juga merangkap sebagai bagian pembuat faktur yang seharusnya dilakukan oleh bagian akuntansi, dan karyawan yang bekerja pada CV. Berkat Karya Diesel Banjarmasin terdiri dari beberapa pegawai bekerja yang tidak sesuai dengan latar pendidikannya sehingga pelaksanaan aktifitas pengendalian intern piutang belum berjalan dengan baik yang mengakibatkan jumlah piutang tak tertagih terus meningkat. Tidak diselenggarakannya pemeriksaan khusus oleh pimpinan perusahaan terhadap pencatatan pengajuan dan penerimaan piutang selama ini. Karyawan yang mutunya 
sesuai dengan tanggungjawabnya. Selama ini karyawan yang bekerja ada perusahaan masih terdiri dari beberapa karyawan bekerja yang belum sesuai dengan latar pendidikannya.

2. Pengendalian intern piutang pada CV Berkat Karya Diesel Banjarmasin yang seharusnya dapat dijalankan sesuai unsur-unsur pengendalian intern adalah dalam struktur organisasi agar Fungsi akuntansi harus terpisah dari fungsi penagihan dan fungsi penerimaan kas, Fungsi penerimaan kas harus terpisah dari fungsi akuntansi. Sistem otorisasi dan prosedur pencatatan agar Debitur diminta untuk melakukan pembayaran dalam bentuk cek atas nama atau dengan cara pemindah bukuan, fungsi penagihan hanya atas dasar daftar piutang. Pengkreditan rekening pembantu piutang oleh fungsi akuntansi (bagian piutang) harus didasarkan atas surat pemberitahuan yang berasal dari debitur. Praktek yang sehat direkam dalam berita acara untuk penerimaan kas, Para penagih dan kasir harus diasuransikan (fidelity bon insurance). Kas dalam perjalanan harus diasuransikan (cash in safe dan crash in transit insurance). Karyawan yang mutunya sesuai dengan tanggungjawabnya pada karyawan yang bekerja ada perusahaan ini agar sesuai dengan latar pendidikannya

\section{DAFTAR PUSTAKA}

Baridwan, Zaki. 2014. Intermediate Accounting Edisi Kedelapan, BPFE, Yogyakarta.

Dwi Martani, dkk. 2014.Akuntansi Keuangan Menengah Berbasis PSAK. Salemba Empat, Jakarta.

Maulinahardi Mirza dan max advian. (2013). Sistem Informasi Akuntansi. Malang: Elektronik Pertama dan Terbesar di Indonesia.

Mulyadi, 2016, Sistem Akuntansi Edisi Keempat, Salemba Empat, Jakarta

Romney, Marshall B., Paul John Steinbart, 2015, Accounting Information Systems, 13th ed. Pearson Educational Limited, England 